\title{
Entomological Index and Vector Distribution of Dengue Hemorrhagic Fever (DHF) Based on Container Characteristics in Kelurahan Cipageran Cimahi
}

\author{
Emma Mardliyah Hidayat* \\ Parasitology Department \\ Universitas Jenderal Achmad Yani \\ Cimahi, Indonesia \\ *emardliyah@gmail.com \\ Desy Linasari \\ Public Health Medicine Department \\ Universitas Jenderal Achmad Yani \\ Cimahi, Indonesia
}

\author{
Syifa Shafira Maulida Rahma \\ Medicine Education \\ Universitas Jenderal Achmad Yani \\ Cimahi, Indonesia
}

\author{
Lutfhi Nulaela \\ Parasitology Department \\ Universitas Jenderal Achmad Yani \\ Cimahi, Indonesia
}

\begin{abstract}
Dengue hemorrhagic fever is an infectious disease infected through the bites of Aedes sp.mosquito. The pattern of DHF incidence fluctuates every year, which is influenced by environmental factors which cover the breeding place of Aedes aegypti Mosquito. One measure taken in controlling the Aedes aegypti mosquito is to locate where the breeding place is. The aim of this study was to determine the potential for breeding place of Aedes aegypti mosquito, the results of this study was the entomology index in Kelurahan Cipageran Cimahi. The study was conducted in 2019 inputted using the REDcap Application with a descriptive method as sampling survey, the number of samples taken was 100 houses. The entomology index of Container Index (CI) was 58,6\%, House Index (HI) was $60 \%$ and Breteau Index(BI) was $153 \%$, while larva free number was $40 \%$. The average dengue vector larvae density based on CI, HI and BI in Kelurahan Cipageran RW 08 scale was 5-8, which fell under the medium risk category. The results showed that the containers with positive larvae of Aedes sp. were found at $60 \%$ which spread almost evenly. Microscopic examination showed that the larvae found were Aedes sp larvae, it was concluded that Aedes sp larvae mostly found in the bathtub and plastic bucket inside the house. The larvae free number recorded in Cipageran Village RW 08 Cimahi was still relatively low, it might occur due to environmental factors like breeding places of Aedes sp. mosquito and the habits of the people who collected water without container cover so that it had the potential to become a breeding place for Aedes aegypti mosquitoes.
\end{abstract}

Keywords-Aedes aegypti, larva free number, breteu index, container index, house index

\section{INTRODUCTION}

Dengue hemorrhagic fever is an infectious disease caused by arthropod borne virus. Borne diseases are infections caused by viruses spreading to humans through infected Arthropod bites [1]. Dengue fever is one of the diseases transmitted through Aedes sp mosquito bite [2]. Aedes Aegypti mosquito is one of the species which plays a role as the main vector of the dengue virus spread in endemic areas, while its main host is humans. The transmission and the spreading from the Aedes Aegypti are affected by environmental conditions [3]. There are three kinds of Aedes sp. mosquitoes in Indonesia that can transmit dengue virus; Aedes aegypti, Aedes albopictus, and Aedes scutellaris [4]. The Dengue Virus (DEN) causing the Dengue Fever comes from the Flaviviridae family and Flavivirus genus [5]. The prevalence of Dengue Fever cases in endemic area each year reaches 50 million cases. Southeast Asia has endemic areas of dengue cases which ranks the first by the number of most cases of DHF every year. Indonesia is an endemic region in Southeast Asia due to its tropical climate and location which lies in the equator. Areas with tropical climate are habitats of the Aedes aegypti mosquitoes [3]. Referring to the data from the World Health Organization (WHO) reported in 2004 and 2010, Indonesia was recorded as the country with the second highest number of Dengue Fever cases among 30 other Dengue Fever endemic countries [6].

Dengue Fever has been the main health concern in Indonesia for the last 41 years. The first incidence of Dengue Fever in Indonesia occurred in 1968 in Jakarta and Surabaya with 58 cases with 24 of whom not surviving with the Case Fatality rate of $41.3 \%$. Since then, Dengue Fever has spread 
widely throughout the nation. In 2007 WHO reported that there were 150,000 Incident Rate (IR), with 25,000 cases among which reportedly originated from Jakarta and West Java regions with CFR of $1 \%$ [3]. The highest Dengue Fever prevalence in 2007 in West Java was in Cirebon District, reaching up to $1.5 \%$, followed by Cimahi, which was $1 \%$ $[7,8]$.

Cimahi consists of 3 Sub districts and 153 kelurahan. All Sub districts in the Cimahi area are endemic to Dengue Fever. According to the report from the Public Health office of Cimahi, there has been a fluctuation in the increase of Dengue Fever cases each year in the last 8 years. In 2012 the number of Dengue Fever cases reported was 899 cases including 5 cases of death with the CFR of $0.65 \%$, while in 2013 there were 957 cases with IR of 171.0/100,000 residents which included 5 cases of death with CFR of $0.52 \%$ [9].

In 2014 there were 512 cases reported with IR of 91.00/100,000 residents, and in 2015 there were 792 cases with IR of 135.00. Meanwhile, the data in 2016 recorded in the Public Health Office of Cimahi indicated an increase of 1080 cases with IR of 185.00/100,000 residents, and in 2017 there was a decrease with 313 Dengue Fever cases recorded with IR of 51.00/100,000 residents with 1 case of death with CFR of $0.3 \%$. There were 292 cases in 2018 with 2 cases of death and IR of 49.00/100,000 residents [10]. According to the report from the Public Health Office of Cimahi in 2019, there was a reported extraordinary event in Cimahi City from January to March, and there were 3 cases of death caused by Dengue Fever with CFR of $0.76 \%$. Meanwhile, the report from the Public Health Office of Cimahi from April to June showed an increase of 89 Dengue Fever - related cases [11].

Based on the recorded data, approximately in the last 8 years, if accumulated, the North Cimahi sub district is the area with the highest Dengue Fever case numbering up to 1,993 cases with fluctuation each year. Kelurahan Cipageran is one of the kelurahans whose topography is located in hilly areas and is an area located in the highest land in Cimahi City. Kelurahan Cipageran is recorded as the area with the highest Dengue Fever Cases in the last 8 years with approximately 528 cases and in 2009 there were 51 cases recorded with IR of 281.00/100,000 residents [11].

Environmental factor is a factor which greatly affects the incidence of Dengue Fever cases. The factor consists of mosquito density, mosquito resting place, and mosquito breeding place [12]. The more disclosed the containers are, the more places will be at risk of being a breeding place for the mosquitos to lay their eggs, and also the denser the Aedes sp. Mosquitoes population can take place so that it may increase the Dengue Fever infection risk [13].

The vector density data measured with the ABJ (Larvaefree number) parameter nationally in 2017 still did not reach the $\geq 95 \%$ target where the ABJ obtained was only $46.7 \%$, not enough to achieve the national target [6]. According to the Public Health Office report in 2019, the ABJ in North Cimahi district, specifically in Kelurahan Cipageran is $87.7 \%$. The number was still below the national standard [11].

After viewing the $A B J$ in Kelurahan Cipageran, which was still below the national standard, it is necessary to take some measures to increase PSN activities by knowing which areas have high risk of being the breeding place of Aedes sp. mosquito larvae and the characteristics of the containers. The places potential enough for Aedes aegypti mosquito larvae to be bred are water storage containers, which are containers used to store water, which can be used for daily usage, like crocks, bathtubs, buckets and non-water storage containers, which are containers to store water which are not used for daily usage like flower vase, used tires, and so on [4]. The container characteristic is seen according to the type, location, condition, color, and water storage materials related with the Aedes aegypti mosquito larvae [14,15].

The entomological index is the Aedes aegypti larvae density indicator parameter in a settlement as a consideration material in determining an effective vector control effort. According to WHO, entomology index is reviewed from the House Index value, which is the percentage of houses containing larvae and pupae, Container Index (CI), which is a percentage of containers containing larvae and pupae, and Breteau Index (BI) which is the number of positive containers per 100 houses examined so that the Larva Free Number $(\mathrm{ABJ} / \mathrm{LFN})$ can be figured out $[16,17]$. The Aedes $s p$. mosquito larvae density is calculated using the Density Figure (DF) scale with the Queensland Government criteria in 2011 which is DF $=1$ (low density), $\mathrm{DF}=2-5$ (medium density) and $\mathrm{DF}=6-9$ (high density) $[17,18]$.

In this study, what differentiates between this study and the previous one was that the researcher would like to know the Entomology index and the Aedes sp. larvae distribution according to the container characteristics in Kelurahan Cipageran RW 08, Cimahi, in which the data result obtained were inputted using REDcap or Research Electronic Data Capture, then processed in the form of a mapping using GIS or Geographic Information System so that they can be used as a preventive measure, vector control, and epidemiology data in that area [19].

\section{MATERIALS AND METHODS}

This study used a descriptive method of survey sampling. This study was conducted in Kelurahan Cipageran RW 08, Cimahi, with the study conducted from November to December 2019. The samples in this study were based on the larvae survey standard set by WHO, which selected 100 houses in the locations determined beforehand, which was Kelurahan Cipageran [16]. Objects in this study were water storage containers and non-water storage containers located both inside and outside of the houses in Kelurahan Cipageran RW 08, Cimahi.

The sample collection was conducted using the random sampling method, where each member had the same chance of being selected as a sample member. The sample collection was 
done using the multistage random sampling method consisting of cluster random sampling method to know which Kelurahan had the highest Dengue Fever case in Cipageran Health Centre working area. Next, the researcher used systematic random sampling from a total of 100 houses sorted according to the number of neighborhoods determined beforehand. The interval of the examined houses was approximately five houses from the house used as the first reference point determined randomly in the neighborhood. From the reference point, the data were obtained from the distance of 5 houses to the right, 5 houses to the left, 5 houses to the front, and 5 houses to the back according to the flying distance of mosquitoes, which is $100 \mathrm{~m}$.

The larva survey form production was done before the research started using the REDcap application (Research Electronic Data Capture). The form contains homeowner identities, container types, container characteristics, and GPS coordinates and the Aedes sp. larvae distributions were mapped using the GIS (Geographic Information System) application. The larvae distribution was marked with dots in the map, where the red dots represent houses with positive larvae and green dots represent houses checked with negative larvae. The Entomology Index calculation is as follows:

$$
\begin{gathered}
A B J=\frac{\sum \text { houses with no larvae present }}{\sum \quad \text { houses or buildings examined }} \times 100 \% \\
H I=\frac{\sum \text { houses with larvae present }}{\sum \text { houses or buildings examined }} \times 100 \% \\
C I=\frac{\sum \text { containers with larvae present }}{\sum \quad \text { containers examined }} \times 100 \% \\
B I=\frac{\sum \text { containers with larvae present }}{\sum \quad \text { houses examined }} \times 100 \%
\end{gathered}
$$

\section{RESULTS AND DISCUSSION}

Based on the larvae survey conducted in 100 houses, it was obtained that Aedes sp. larvae were found in most houses. In this study, the Aedes sp. Larvae examination was conducted using the single larva method where larvae found were taken as samples and stored in a scoop as a temporary storage before an identification was performed. The type of larva was identified using macroscopic and microscopic examinations using a stereo zoom microscope in the Parasitology Laboratory of the Faculty of Medicine in Unjani. The larvae type observation conducted through sampling showed a morphology result concluding that most of the larvae are Aedes sp. Aedes sp. Fig. 1 shows the identification of Aedes spl Larvae. Aedes sp larvae have thin bodies, move fast, and have negative phototaxis characteristics, and during their resting they form almost straight angles adjacent to the water surface.

\section{A. Distribution of Houses in RW 08 Positive with Aedes sp. Larvae}

The larvae survey conducted in RW 08 in Kelurahan Cipageran showed that most houses were positive with Aedes $s p$. larvae. The mapping result using REDcap and GIS is shown in Fig. 2. The figure shows house distribution, with red dots representing houses positive with Aedes sp. larvae while green dots represent houses with no Aedes sp. larvae present. The distribution of the houses with larvae present was distributed evenly in each location visited. Table 1 shows the number of houses with Aedes sp. larvae present and Larvae-free houses . There were 60 houses positive with larvae, and 40 houses were negative or Aedes sp. larvae free.

The presence of larvae in an area is related to Dengue Fever. Factors affecting Dengue Fever cases are host, agent or dengue virus, and environmental factors, which is one of the most important factors related to dengue infection [20]. Larvae presence around human settlements are related to the presence of open containers the lack of PSN application and the behavior of the society towards vector control, which is in line with the study conducted in Samarinda [21].
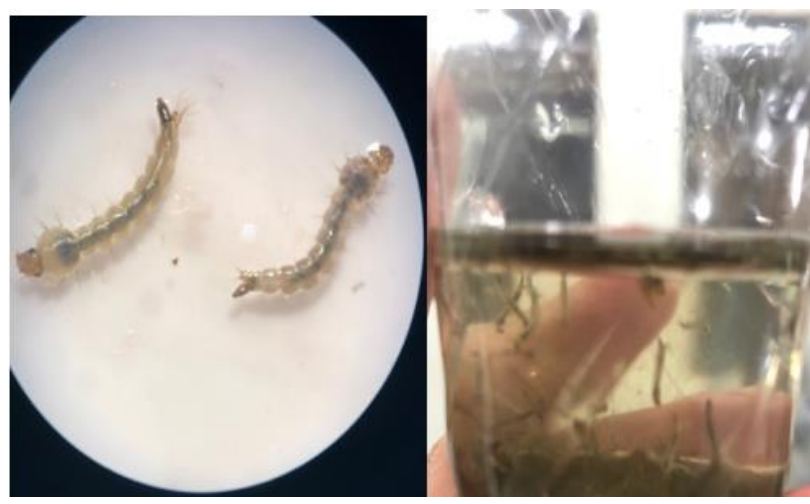

Fig. 1. Aedes sp. larvae.

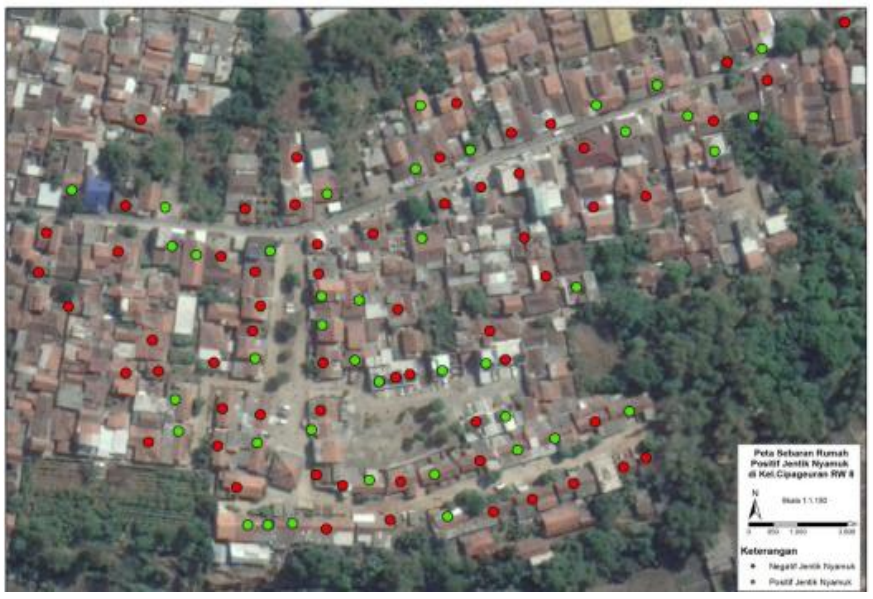

Fig. 2. The mapping of houses positive with Aedes sp. in Kelurahan Cipageran RW 08 Cimahi.

TABLE I. THE DISTRIBUTION OF AEDES SP. LARVAE PRESENCE IN HOUSES LOCATED IN KELURAHAN CIPAGERAN RW 08

\begin{tabular}{|c|c|c|}
\hline Larvae Presence & Frequency & Percentage (\%) \\
\hline Positive & 60 & 60.0 \\
\hline Negative & 40 & 40,0 \\
\hline Total & 100 & 100,0 \\
\hline
\end{tabular}




\section{B. Container Types Positive with Aedes sp}

Table 2 depicts the study of 261 containers. The water storage containers commonly used were buckets, where 78 out of 100 houses visited used buckets to store water, and 68 houses were recorded to still use bathtubs for storing water used for daily usage. Drum containers were limited, which was present only at 17 houses, while 5 houses used crocks. Kelurahan Cipageran is a fairly dense settlement area, and the study result showed that all visited houses had water storage, which were water storage containers and non-water storage containers. The behavior of the residents, which always stored water in that area, also affected the presence of Aedes sp. larvae because it is its ideal habitat, Aedes $s p$. Resides in places with clean standing water indirectly not in contact with the ground [6]. This study is in accordance with the previous study which stated that the bathtub container was one of the water storage containers in which larvae were commonly found [22]. Breeding places with small volume such as flower vase and used tires become non-water storage containers with the highest percentage, because such containers are potential breeding places for Aedes aegypti larvae. This was so because residents did not expend and drain water contained in the containers [23]. The shortage of water this month forces the residents to store water in a container and disclose the containers for daily purpose in the water container storage placed inside the bathroom or outside the house. In the end, water storage containers which should have been used for daily purpose make potential breeding places for adult Aedes sp.

TABLE II. TYPES OF CONTAINERS AND AEDES AEGYPTI LARVAE PRESENCE EXAMINED KELURAHAN CIPAGERAN RW 08 IN 2019.

\begin{tabular}{|c|c|c|c|c|c|c|}
\hline \multirow[t]{2}{*}{$\begin{array}{c}\text { Types of } \\
\text { Containers } \\
\text { Examined in } \\
100 \text { houses in } \\
\text { RW 08 }\end{array}$} & \multicolumn{2}{|c|}{$\begin{array}{c}\text { Containers } \\
\text { Negative with } \\
\text { Aedes Aegepti } \\
\text { Larvae }\end{array}$} & \multicolumn{2}{|c|}{$\begin{array}{c}\text { Containers } \\
\text { positive with } \\
\text { Aedes aegypti } \\
\text { Larvae }\end{array}$} & \multicolumn{2}{|c|}{$\begin{array}{l}\text { Number of } \\
\text { Containers } \\
\text { Examined }\end{array}$} \\
\hline & $n$ & $\%$ & $n$ & $\%$ & $n$ & $\%$ \\
\hline \multicolumn{7}{|c|}{ Water storage containers } \\
\hline Drums & 10 & 58.8 & 7 & 41.2 & 17 & 100.0 \\
\hline Bathtubs & 28 & 41.2 & 40 & 58.8 & 68 & 100.0 \\
\hline Crocks & 2 & 40.0 & 3 & 60.0 & 5 & 100.0 \\
\hline Buckets & 38 & 48.7 & 40 & 51.3 & 78 & 100.0 \\
\hline Total & 78 & & 90 & & 168 & \\
\hline \multicolumn{7}{|c|}{ Non water storage containers } \\
\hline Flower Vase & - & - & 1 & 100.0 & 1 & 100.0 \\
\hline Used Tires & - & - & 2 & 100.0 & 2 & 100.0 \\
\hline Used Cans & 8 & 53.3 & 7 & 46.7 & 15 & 100.0 \\
\hline $\begin{array}{l}\text { Drinking Water } \\
\text { Dispenser }\end{array}$ & 19 & 27.5 & 50 & 72.5 & 69 & 100.0 \\
\hline Used Bottles & 3 & 50.0 & 3 & 50.0 & 6 & 100.0 \\
\hline Total & 30 & & 63 & & 93 & \\
\hline
\end{tabular}

\section{Dengue Fever Entomology Indicators in Kelurahan Cipageran $R W 08$}

The vector entomology index of Dengue Fever on table 3 is one of the indicators to determine whether or not the area has a potential to develop Dengue Fever cases annually [24]. The ABJ (Larvae Free number) on the table shows the value of $40 \%$ which means that in the area the ABJ value was far below the national standard which is $<95 \%$. This increases the chance of occurrence of the Dengue Fever virus transmission [4]. House Index is the percentage of houses which are larvae positive. The value is high if the HI value $\geq 10 \%$. Container Index is the information regarding the number of water storage that is positive with larvae. The value is high if CI value $\geq 5 \%$. Breteu Index is the number of water storage positive with larvae per 100 examined houses. The value is high if the BI value $\geq 50 \%$. Density Figure (DF) is a scale of Aedes aegypti larvae density based on the Entomology Index value in this study. The DF scale shows that the larvae density in the area was in the medium category. Entomology Indicators covering HI, CI and BI are not always followed by the high number of Dengue Fever cases in a certain area. This is because Dengue Fever cases can also be affected by several other factors like virus strains, virus titer, the biting behavior of the mosquitoes, immunity of the residents, climate, population density, and the vulnerability of a person towards the dengue virus [4].

TABLE III. ENTOMOLOGY INDICATORS IN KELURAHAN CIPAGERAN RW 08 IN 2019.

\begin{tabular}{|l|c|c|}
\hline \multicolumn{2}{|c|}{$\begin{array}{c}\text { Entomology Index from 100 houses in } \\
\text { RW 08 }\end{array}$} & Density Figure (DF) \\
\hline Larvae Free Number (ABJ) & $40 \%$ & - \\
\hline House Index (HI) & $60 \%$ & 8 (medium density) \\
\hline Container Index (CI) & $58.6 \%$ & 9 (medium density) \\
\hline Breteu Index & $153 \%$ & 8 (high density) \\
\hline
\end{tabular}

\section{Distribution of Aedes Aegypti Larvae Based on the Container Characteristics}

The table 4 shows the distribution of larvae presence based on several different container characteristics. The study of larvae presence in containers with water volume more than or less than 50 litres showed high Aedes sp. larvae density in containers with volume $<50$ liters with a percentage of $63.6 \%$, while in the containers with volume $>50$ liters the percentage was $53.6 \%$. Container characteristics with small or big volume had the same potential with larvae presence. Containers with big volume have the capacity to store more water so that the water inside stay long enough and becomes difficult to be drained, making them potential breeding places for Aedes sp. larvae. This is also influenced by Aedes sp. mosquito bionomic which prefer clean standing water in containers with volume less or more than 50 liters [25]. The study result showed that larvae presence was commonly found in water storage originated from dug wells with a percentage of $60.8 \%$ but the cause is yet to be discovered. This corresponds to the Aedes sp. mosquitoes' habitats which can live and breed in clean water. According to the bionomic of Aedes sp. They prefer clean water storage, hidden from the sunlight for their breeding place, and such storage was commonly found inside and around houses [26]. 
TABLE IV THE DistRIBUtION OF AEDES AEGYPTI LARVAE PRESENCE BASED ON CONTAINER CHARACTERISTICS

\begin{tabular}{|c|c|c|c|c|c|c|}
\hline \multirow{3}{*}{ Variables } & \multicolumn{4}{|c|}{ Larvae Presence } & \multirow{2}{*}{\multicolumn{2}{|c|}{$\begin{array}{c}\text { Total } \\
\text { Containers }\end{array}$}} \\
\hline & \multicolumn{2}{|c|}{ (+) Larvae } & \multicolumn{2}{|c|}{ (-) Larvae } & & \\
\hline & $n$ & $\%$ & $n$ & $\%$ & $n$ & $\%$ \\
\hline \multicolumn{7}{|c|}{ Container Volume } \\
\hline$>50$ liters & 90 & 53.6 & 78 & 46.4 & 168 & 100.0 \\
\hline$<50$ liters & 63 & 63.6 & 36 & 36.4 & 99 & 100.0 \\
\hline \multicolumn{7}{|c|}{ Water Source } \\
\hline Dug Well & 59 & 60.8 & 38 & 39.3 & 97 & 100.0 \\
\hline $\begin{array}{c}\text { National Water } \\
\text { Company }\end{array}$ & 1 & 33.3 & 2 & 66.7 & 3 & $100 / 0$ \\
\hline \multicolumn{7}{|c|}{ Container Cover } \\
\hline Present & 3 & 18.8 & 13 & 81.3 & 16 & 100.0 \\
\hline Not Present & 149 & 59.4 & 102 & 40.6 & 251 & 100.0 \\
\hline \multicolumn{7}{|c|}{ Container Location } \\
\hline Inside the house & 124 & 52.3 & 113 & 47.7 & 237 & 100.0 \\
\hline $\begin{array}{c}\text { Outside the } \\
\text { house }\end{array}$ & 29 & 96.7 & 1 & 3.3 & 30 & 100.0 \\
\hline \multicolumn{7}{|c|}{ Container Material } \\
\hline Cement & 20 & 66.7 & 10 & 33.3 & 30 & 100.0 \\
\hline Ceramic & 30 & 78.9 & 8 & 21.1 & 38 & 100.0 \\
\hline Plastic & 103 & 51.8 & 96 & 48.2 & 199 & 100.0 \\
\hline \multicolumn{7}{|c|}{ Container Color } \\
\hline Dark & 140 & 91.5 & 13 & 11.4 & 153 & 100.0 \\
\hline Bright & 13 & 11.4 & 101 & 88.6 & 114 & 100.0 \\
\hline
\end{tabular}

The distribution of container cover in relation with Aedes $s p$. larvae presence showed a higher number of larvae found in containers without covers, with a percentage of $59.4 \%$ compared to containers with covers with a percentage of $18.8 \%$. This is in accordance with the government program, PSN, one of whose programs is to close water storage containers because female Aedes aegypti mosquitoes are easier to lay their eggs in water puddles without covers [4]. The examined containers inside the houses had a larvae-positive percentage of $52.3 \%$ and outside the houses of $96.7 \%$. Containers outside the houses had a higher percentage of Aedes $s p$. larvae presence. This was related to the society's behavior to do PSN in which one of the included measures is to close containers. Disclosing containers outside houses and leaving them without covers increase the potential for Aedes sp. larvae to be found.

Another characteristic is the container material. In this study, the potential materials were ceramic, which had an Aedes aegypti larvae-positive percentage of $78.9 \%$. This occurred because of the habit of storing water in media that were disclosed, and also not trying to control the breeding place of Aedes sp. by using temphos and the existence of mosquito bionomic regarding its breeding place in which it prefers standing water, causing ceramic-based containers to have higher percentage of Aedes sp. percentage. Differences in container colors caused percentage differences of the presence of Aedes aegypti larvae. Dark colored containers had a higher percentage of Aedes aegypti presence with 91.5\%. The dark color in the container could provide Aedes aegypti mosquitoes a secure and calm sensation while they are laying eggs, so the eggs laid are higher in numbers [15].

\section{CONCLUSION}

Based on the research above, it can be concluded that the entomology index result consisting of $\mathrm{HI}$ is $60 \%$ with $\mathrm{DF}$ value of $8, \mathrm{BI}$ of $153 \%$ with DF value of 8 , and CI of $57.3 \%$ with DF of 9 and the Larvae Free Number in Kelurahan Cipageran RW 08, Cimahi shows a percentage of $40 \%$. Density Figure shows a medium scale of infection risk of Dengue Fever in the study areas. The mapped house distribution using REDcap and GIS in Kelurahan Cipageran RW 08 Cimahi showed that 60 out of 100 houses were positive with larvae, and 40 houses were negative with larvae with even distribution. The type of larvae found in the samples taken from the residents' houses were Aedes sp.

Container characteristics with high potential of Aedes $s p$. larvae breeding places were those with the volume of $<50$ litres, dug well sourced in 93 houses, no covers, outside the houses, ceramic based and dark colored. The types of Water Storage Containers which had high potential of containing larvae were crocks and bathtubs and non-water storage containers were flower vase and used tires.

\section{ACKNOWLEDGMENT}

The author wish to thank LPPM Universitas Jenderal Achmad Yani for supporting this research.

\section{REFERENCES}

[1] M.T.O. Mota, A.C. Terzian, and M.L.C.R. Silva, "Mosquito transmitted viruses - the great Brazilian challenge," Brazilian J Microbiol, vol. 47 , pp. 38-50, 2016.

[2] R.I. Pahlepi, S.R.E. Soviana, "Kepadatan dan karakteristik habitat larva aedes sp di SD daerah endemis DBD Kota Palembang," Spirakel, vol. 9, pp. 68-78, 2017.

[3] World Health Organization (WHO), Dengue guidelines for diagnosis, treatment, prevention and control. Geneva: WHO, 2009.

[4] Kementrian Kesehatan Republik Indonesia (Kemenkes), "Pedoman pencegahan dan pengendalian demam berdarah dengue di Indonesia," Journal of Cardiovascular Medicine, vol. 1, pp. 1-128, 2017.

[5] B.W. Johnson, B.J. Russell, and R.S. Lanciotti, "Serotype specific detection of dengue viruses in a fourplex real time reverse transcriptase PCR assay," J Clin Microbiol, vol. 43, pp. 4977-4983, 2005.

[6] Kementrian Kesehatan Republik Indonesia (Kemenkes), Info Datin situasi demam berdarah dengue, Jakarta: KEMENKES, 2017.

[7] U.F. Achmadi, P. Sudjana, and S. Sukowati, Jendela epidemiologi demam berdarah dengue. Jakarta: KEMENKES, 2010.

[8] F.Y. Pradani, M.E.A. Fuadiyah, and Y. Yuliasih, "Perilaku masyarakat dan indeks entomologi vektor demam berdarah dengue di Kota Cimahi," ASPIRATOR - J Vector-borne Dis Stud., vol. 2, pp. 37-44, 2010.

[9] Dinas Kesehatan (Dinkes), Profil Kesehatan Kota Cimahi Tahun 2013. Cimahi: Dinkes, 2013.

[10] Dinas Kesehatan (Dinkes), Profil Kesehatan Kota Cimahi Tahun 2017. Cimahi: Dinkes, 2017.

[11] Dinas Kesehatan (Dinkes), Laporan Kasus DBD Kota Cimahi Tahun 2019. Cimahi: Dinkes, 2019.

[12] M. Marwanty, and T.Y.M. Wahyono, "Faktor lingkungan rumah dan kejadian demam berdarah dengue di Kota Palopo 2016," J Epidemiologi Kesehatan Indonesia, vol. 2, pp. 19-26, 2019. 
[13] K.S. Fathi, and C.U. Wahyuni, "Peran faktor lingkungan dan perilaku terhadap DBD di Kota Mataram," J Kesehatan Lingkungan, vol. 1, pp. $1-11,2005$.

[14] W. Wanti and M. Darman, "Tempat penampungan air dan kepadatan jentik Aedes sp. di daerah endemis dan bebas demam berdarah dengue,' Kesmas: National Public Health Journal, vol. 9, pp. 171-178, 2014.

[15] A. Budiyanto, "Perbedaan warna kontainer berkaitan dengan keberadaan jentik aedes aegypti di Sekolah Dasar," J Biotek Medisiana Indonesia, vol. 1, pp. 63-71, 2012.

[16] World Health Organization (WHO), Comprehensive guidelines for prevention and control of dengue and dengue haemorrhagic fever. WHO. Regional Publication SEARO, 2011.

[17] A.S.W. Joharina, "Kepadatan larva nyamuk vektor sebagai indikator penularan demam berdarah dengue di daerah endemis di Jawa Timur," J Vektor Penyakit, vol. 8, pp. 33-40, 2014.

[18] D.A. Focks, A review of entomological sampling methods and indicators for dengue vector. Geneva: World Health Organization, 2003.

[19] F.F. Patridge and T.P. Bardyn, "Research Electronic Data Capture (REDCap),” J Med Libr Assoc., vol. 106, pp. 142-144, 2018.

[20] H. Prasetyowati, E.P. Astuti, and M. Widawati, "Faktor yang Berhubungan dengan Keberadaan Jentik Aedes aegypti di Daerah Endemis Demam Berdarah Dengue (DBD) Jakarta Barat," Balaba J Litbang Pengendali Penyakit Bersumber Binatang Banjarnegara, vol. 13, 2017.
[21] A. Pujiyanti, "Peran Pengetahuan Dan Tingkat Pendidikan Terhadap Perilaku Pengendalian Vektor Dbd Pada Masyarakat Di Kelurahan Endemis Di Kota Samarinda Tahun 2009," Vektora, vol. 6, pp. 41-45, 2014.

[22] A.B. Purnamasari, S. Kadir, and Marhtyni, "Distribusi Keruangan Spesies Larva Aedes sp. Dan Karakterstik Tempat Perkembangbiakan Di Kelurahan Karunrung Kota Makasar,” Bionature, vol. 17, pp. 7-13, 2016.

[23] J.A. Majid, M. Sulaiman, S. Zailani, M.R. Shaharudin, B. Saw, C.L. $\mathrm{Wu}$, "Hubungan tempat perindukan nyamuk dan perilaku pemberantasan sarang nyamuk (PSN) dengan keberadaan jentik Aedes aegypti di Kelurahan Benda Baru Kota Tangerang Selatan Tahun 2015," Acta Univ Agric Silvic Mendelianae Brun, vol. 16, pp. 39-55, 2015.

[24] D. Perwitasari, R.N. Res, and J. Ariati, "Indeks Entomologi dan Sebaran Vektor Demam Berdarah Dengue di Provinsi Maluku Utara Tahun 2015," Media Peneliti dan Pengembangan Kesehatan, vol. 28, pp. 279$288,2018$.

[25] I. Arfan, "Keberadaan jentik aedes sp berdasarkan karakteristik kontainer di daerah endemis dan non endemis demam berdarah dengue," J. Ilmiah Ilmu Kesehatan Wawasan Kesehatan, vol. 5, pp. 258-66, 2019.

[26] S.N. Hammond, A.L. Gordon, E.D.C. Lugo, G. Moreno, G.M. Kuan, M.M. López, "Characterization of Aedes aegypti (Diptera: Culcidae) Production Sites in Urban Nicaragua," J Med Entomol, vol. 44, pp. 851860, 2007. 